\title{
Nutricional value of two protein hydolysates selected for the design of a new therapeutic infant formula
}

\author{
Esther Matencio ${ }^{*}$, Sergio Muñoz ${ }^{2}$, Josune Olza², Saray Santamaría², Fernando Romero ${ }^{3}$, Pedro Abellán ${ }^{3}$, Angel Gil ${ }^{2}$ \\ From Food Allergy and Anaphylaxis Meeting 2011 \\ Venice, Italy. 17-19 February 2011
}

\section{Background}

Breastfeeding is the gold standard of infant feeding, however not all infants with cow's milk protein allergy (CMPA) tolerate human milk. In these cases, it seems recommended the use of extensively hydrolyzed formula (eHF). Preliminary analyses such as antigenicity and protein quality evaluation are needed to ensure that new formula will be nutritionally suitable, tolerated and safe for infants with CMPA. The aim of this study was to determine the protein quality of a whey hydrolysate $(\mathrm{WH})$ and casein hydrolysate $(\mathrm{CH})$.

\section{Methods}

The Thomas-Mitchell method modified was used. Male Wistar rats weighing about $50 \mathrm{~g}$ were housed in metabolic cages and distributed in three groups fed with diets only differ in protein source. Group 1 fed with $\mathrm{WH}$, group 2 fed with $\mathrm{CH}$ and group 3 fed with casein $+5 \%$ DL-methionine reference diet. Acclimatization of five days followed of ten days with experimental diet. In the last seven days we controlled daily intakes and collected faeces and urine. For estimation of the protein quality, true digestibility, net protein utilization (NPU), biological value (BV) and protein efficiency ratio (PER), were used. Nitrogen content was measured by means of Kjeldahl method in diet, faeces and urine.

\section{Results}

WH and $\mathrm{CH}$ showed similar NPU $(67,18 \%, 69,55 \%), \mathrm{BV}$ $(72,99 \%, 75,26 \%)$ and PER $(3,62,3,69))$. NPU, BV and PER in control diet were $(81,01 \%, 85,64 \%$ and 4,14$)$.Both hydrolysates complied with the requirements of PER

${ }^{1}$ Hero Institute for Infant Nutrition, Research, Spain

Full list of author information is available at the end of the article higher than 2.5 and BV higher than 70, considered as adequate sources of amino nitrogen for human nutrition.

\section{Conclusions}

$\mathrm{WH}$ and $\mathrm{CH}$ are good protein sources to be used in the design of a new eHF for the nutritional treatment of infants with CMPA.

\section{Author details}

${ }^{1}$ Hero Institute for Infant Nutrition, Research, Spain. ${ }^{2}$ Institute of Nutrition and Food Technology. Centre of Biomedical Research University of Granada, Biochemistry and Molecular Biology II., Granada, Spain. ${ }^{3}$ Hero Institute for Infant Nutrition, Research, Murcia, Spain.

Published: 12 August 2011

doi:10.1186/2045-7022-1-S1-P113

Cite this article as: Matencio et al:: Nutricional value of two protein

hydolysates selected for the design of a new therapeutic infant

formula. Clinical and Translational Allergy 2011 1(Suppl 1):P113.

Submit your next manuscript to BioMed Central and take full advantage of:

- Convenient online submission

- Thorough peer review

- No space constraints or color figure charges

- Immediate publication on acceptance

- Inclusion in PubMed, CAS, Scopus and Google Scholar

- Research which is freely available for redistribution

\section{Ciomed Central}

(c) 2011 Matencio et al; licensee BioMed Central Ltd. This is an open access article distributed under the terms of the Creative Commons Attribution License (http://creativecommons.org/licenses/by/2.0), which permits unrestricted use, distribution, and reproduction in any medium, provided the original work is properly cited. 